\title{
PROJECT SUCCESS: ROLE OF ORGANISATION STRENGTHS AND PROJECT MANAGEMENT COMPETENCIES
}

\section{Samman Ayyaz ${ }^{1 *}$, Rao Aamir Khan ${ }^{2}$, Sohail Aslam ${ }^{3}$, Muhammad Khushnood $^{4}$, Humera Manzoor $^{5}$}

${ }^{1 *, 2}$ Department of Management Sciences, Comsats University Islamabad (CUI), Pakistan; ${ }^{3}$ Department of Project and

Operation Management, The Islamia University of Bahawalpur, Pakistan; ${ }^{4,5}$ Institute of Business Studies, Kohat

University of Science and Technology (KUST), Pakistan.

Email: ${ }^{*}$ sammanzehra20@gmail.com, ${ }^{2}$ rao_aamir@comsats.edu.pk, ${ }^{3}$ sohail.aslam@iub.edu.pk,

${ }^{4}$ mkhushnood@kust.edu.pk, ${ }^{5}$ humera@kust.edu.pk

Article History: Received on $10^{\text {th }}$ April 2021, Revised on $18^{\text {th }}$ May 2021, Published on $24^{\text {th }}$ May 2021

\begin{abstract}
Purpose of the study: This research examines the major organisation strength factors, important project management competencies, and the criteria for project success, and their interrelationship.

Methodology: A mixed-method approach is applied with a positivist stance to test the validity of the proposed hypotheses. Based on the detailed literature review and five expert interviews, 'organisation strengths' are identified and classified into three subcategories, making a second-order construct. A survey strategy is used to collect data from PMO individuals of construction organisations. SmartPLS software is used to analyse 97 responses.
\end{abstract}

Main Findings: The results of this study support the proposed relationship. It suggests that organisation strengths influence project management competencies and project success. Furthermore, resources and capabilities influence project success. The findings are in line with the literature suggesting that organisation resources and capabilities are important for project success.

Application of the study: This study is relevant for PMO individuals, especially in construction organisations. The findings highlight the importance of organisational strengths that lead to build project management competencies and eventually attain project success. These organisational strengths are of great significance to both the researchers and industry practitioners.

The originality of the study: This study has applied a mixed-method approach. The model in the study empirically tests the organisation strength factors affecting project success. Furthermore, the study used SmartPLS software to test the influence of organisation strength to increase project management competencies and their cumulative effect on project success.

Keywords: Project Management Competencies, Project Success, Organisation Strength, Construction Projects.

\section{INTRODUCTION}

A project is an effective approach, besides other industries, in the construction business. Construction projects are of different types in complexity and size (Alzahrani et al., 2013, Isik, Arditi, Dikmen, \& Birgonul, 2009). There is tough competition in the business world, particularly in the construction industry. Construction companies rely on their competitive advantages to survive in a competitive business market (Gudiene, Banaitis, Podvezko, \& Banaitiené, 2014; Shin, 2012). The competition makes it imperative for construction organisations to focus on their strengths for achieving project success (Gumilar, Zarnić, \& Selih, 2015; Castro, Bahli, Barcaui, \& Figueiredo, 2020; Zuo et al., 2018; Belout \& Gauvreau, 2004). Successful construction projects are important for the country's development because these provide physical infrastructures such as roads, dams, parks, museums, and overpasses. Successful completion of projects, particularly in the construction industry in Pakistan, is a serious issue to be focused on ( $\mathrm{Saad}$, Zahid, \& Muhammad, 2020). Therefore, it is relevant to study the project success factors in the context of the construction industry in Pakistan.

Organisational strengths play the main role in leading business (Bocken \& Geradts, 2020). Organisatios should be aware of their strengths and weaknesses to cope with the challenges of increased competition (Mir \& Pinnington, 2014). Organisations with the capability to utilize their strengths are more successful (de Bakke, Boonstra, \& Wortmann, 2012). An organisation with the least focus on its strength factors cannot survive in the competitive business environment (Fells, 2000; Lieshout et al., 2020). It is important to know project management competencies, implications, and usage in construction projects (Remidez \& Jones, 2012).

Project management competencies act like a catalyst in the production of successful construction projects along with organisation strengths (Chen et al., 2019; Hwang \& Ng, 2013; Madter, Bower, \& Aritua, 2012; Saad et al., 2020; Müller, Glückler, \& Aubry, 2013). Competency can be used as a tool to improve organisational efficiency and meet the objectives and goals of the specific project. Most construction companies develop competency maps for their businesses (Remidez \& Jones, 2012; Upadhyay \& Kumar, 2020).

It would be worthwhile to find out those organisational strengths that would lead the construction projects towards success. Indeed, several significant studies have recently been done on projects and organisation strengths. Many researchers have talked about organisation strengths, project success, success criteria, and management competencies 
separately, and they focus on specific projects and specific country situations (Hwang \& Ng, 2013; Remidez \& Jones, 2012; Abdul-rahman, Wang, \& Muhammad, 2011; Müller et al., 2013). Previous studies have not holistically considered the effect of organisation strengths and project management competencies on project success. There is little empirical research on the success factors of construction projects in Pakistan (Saad et al., 2020). It is worthy of building a performance measurement model for the success of projects in construction organisations in Pakistan.

\section{This study explores the relationship between project success and its assumed antecedents in the construction industry located in twin cities of Rawalpindi and Islamabad, Pakistan.}

To empirically test the relationship between the factors under consideration, data is obtained from construction organisations and analysed using Structural Equation Modeling (SEM). The following sections present a literature review on the variables of the study's conceptual framework, method relevant to the purpose of the study, data collection approach, sampling technique, data analysis method, results, discussion, and conclusion.

\section{LITERATURE REVIEW}

There have been numerous discussions in the literature about construction organisations, organisation strengths and project success. The construction organisation is necessary for the development of the state (Rodríguez-Rivero, OrtizMarcos, Díaz-Barcos, \& Lozano, 2020; Meng, 2012). Construction projects in Pakistan are generally focused on physical infrastructure development, irrigation, transportation, and agriculture (Saad et al., 2020; Doloi, 2009). It is the upcoming need of Pakistan to reform construction organisations (Choudhry, Hinze, Arshad, \& Gabriel, 2012; Kulshreshtha, 2008). Choudhry et al. (2012) examined that in Pakistan, the construction organisations lack the latest tools and techniques; somehow, they do not have the latest machinery as this is the drawback of the construction industry, which fails construction projects. To avoid failure, organisations need to focus on their strengths (Müller et al., 2013). The literature seems to emphasise project-related factors connected to organisational resources and capabilities, organisational strategies, and relationships of organisation with other partners.

Performance and success are the goals of all construction projects (Pheng \& Chuan, 2006; Abdul-rahman et al., 2011; Ghoddousi \& Hosseini, 2012). The success level in construction projects depends upon quality, time, cost, safety, and political stability (Choudhry et al., 2012). Many construction industries face delays in construction projects. The level of uncertainty in the construction sector is on the higher side as compared to other industries, thus, there is a need to develop a frame of organisation strength factors to avoid delay and failures in construction projects (Ghoddousi \& Hosseini, 2012). For complex construction projects, the strengths of the organisation are critical for the successful accomplishment of construction projects (Shin, 2012).

\section{Organisation Strengths}

If a construction company has enough command on success factors, it will become the organisation's strength (Müller et al., 2013). It is not easy to categorise some characteristics of organisations as strengths due to the nature of these characteristics (Abdul-Aziz, 2011). The strength of the organisation is that it can result in the sense of fulfillment of all the needs of stakeholders (Zuo et al., 2018; Daniel, Agarwal, \& Stewart, 2013). Organisations, having the ability to utilize the strengths, can complete projects successfully (de Bakker et al., 2012). Many construction organisations are less competitive as they have more weaknesses than strengths (Abdul-Aziz, 2011). Organisation strengths determine the success of projects (Mir \& Pinnington, 2014, Daniel et al., 2013).

Both the academician and practitioners have a keen interest to find out the organisation strengths. Munns and Bjeirmi (1996) explained that the organisation strengths include project completion on time, proper project planning, skilled project manager, project information flow, change accommodation, employees rewarding, and implementing innovations, leadership, financial resources, technical competency, experienced staff, proper planning, trust, different strategies, and relationship with other parties (Munns \& Bjeirmi, 1996).

The resources and capabilities of an organisation are effective organisation strengths (Isik et al.,2009). The success of the construction projects depends upon the organisation strengths including managerial skills, financial skills, technical skills, relationship with other parties, management of risks, and political stability (Rodríguez-Rivero et al., 2020; Daniel et al., 2013).

Researchers argue that human factors play an important role in project success (Müller et al., 2013; Castro et al., 2020; Shahhosseini \& Sebt, 2011). Ng et al. (2009) extracted seventeen (17) strength factors classified into six components that are: market position, human resources, equipment-related factors, finance, managerial abilities, and project successrelated factors. Saqib, Farooqui, and Lodi (2008) grouped organisation strengths into seven categories: factors of project management, client-related factors, procurement factors, project manager-related factors, design team-related factors, contractor-related factors, business, and work environment-related factors. Frodell et al. (2008) grouped strengths under five groups: project-related factors, environment, relationship with other parties, resources and capabilities, and poor equipment and raw materials, having a maximum influence on the project's performance.

Arslan and Kivrak (2008) identified three success factors leading to the construction company's success: financial conditions, business management, and owner/manager characteristics. Tan et al. (2007) identified six categories of 
organisation strengths for measuring competitiveness in the Hong Kong construction industry: the image of the company, financing ability, marketing strategy, technical ability, management skills, and human resources power.

Organisation strengths are categorised into three major categories: organisation's resources and capabilities, organisational decisions, and stakeholder networking (Isik et al., 2009). Resources and capabilities reflect eleven indicators, strategic decisions include ten indicators, and networking strengths include seven indicators (Westerveld et al., 2003, Müller et al., 2011, Mir \& Pinnington, 2014, Alzahrani et al., 2013).

\section{Resources and Capabilities}

Organisation resources and capabilities are the broader categories of organisation strength, and they play an important role in organisation performance. Many success factors merge in the category of resources and capabilities. The resources and capabilities are the organisation's dimension that eventually leads the project towards success (Zuo et al., 2018). An organisation's resources and capabilities could be the tangible and intangible assets of the organisation (Frodell et al., 2008).

\section{Strategic Decisions}

Strategic decisions are different in different countries according to industries and country situations (Rodríguez-Rivero et al., 2020). Strategic decisions will meet recent challenges globally, and strategies tell which technologies to be adapted (Mir \& Pinnington, 2014).

\section{Strength of Relationship with Other Parties}

An organisation's relationships with stakeholders are the dimension of an organisation strength (Saad et al., 2020). In construction projects, relationships with stakeholders involve material suppliers, public or private clients, contractors and subcontractors, labourers, different companies, mandatory agencies, and financial institutions (Madter et al., 2012). To build cooperation and combine satisfaction among parties, the relationship between them should be strong and trustworthy. Business parties should value each other. In any business, the stakeholder's satisfaction is the key to a successful business, especially in construction companies. The satisfaction of primary and secondary relationship from higher authorities to lower staff is very important (Belout \& Gauvreau, 2004; Sergeeva \& Ali, 2020).

\section{Project Management Competencies}

Competency is the capability to work efficiently to meet the required goals and objectives (Shahhosseini \& Sebt, 2011; Hwang \& Ng, 2013). Project management competencies are the abilities and capabilities to manage the project to meet the project goals and objectives, leading to project success (Isik et al., 2009; Hwang \& Ng, 2013). Project management is an approach to ensure project success, particularly in the construction business. In almost all projects, the implementation of projects is the same (Madter et al., 2012). Ten knowledge areas from PMBOK (2017) are considered the project management competencies. During the project's implementation process, these management competencies are found to have a potential impact on project success (Shahhosseini \& Sebt, 2011; Madter et al., 2012; Remidez \& Jones, 2012, Müller et al., 2013).

\section{Project Success}

Project success refers to the accomplishment of the overall objectives of the project. A project that meets project stakeholder expectations is called project success (Westerveld et al., 2003; Castro et al., 2020). Project success itself is a complex issue. The main issues leading to project failure are lack of adequate and proper planning, shortage of resources, shortage of funds, and employee incompetency (Müller et al., 2011).

As mentioned earlier, literature review and five expert interviews are used to develop research framework (see figure 1).

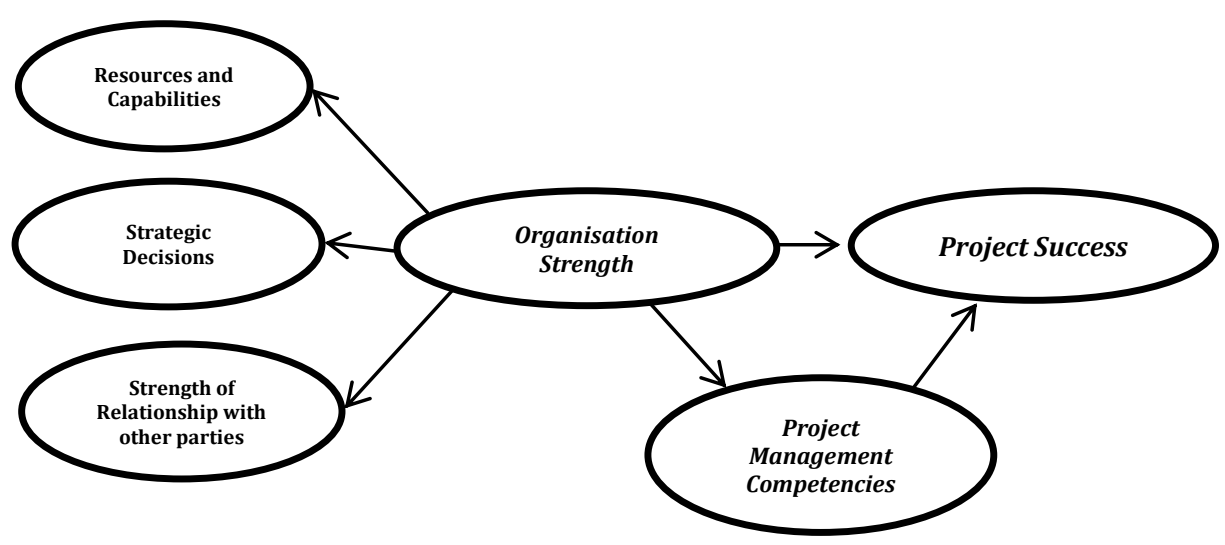

Figure 1: Conceptual Model of the study

Source: Conceived by authors 
The following main hypotheses are drawn from the literature review findings.

Hypothesis $1\left(\mathbf{H}_{1}\right)$ : There is a positive influence of organisation strength on project management competencies.

Hypothesis $\mathbf{2}\left(\mathbf{H}_{2}\right)$ : There is a positive influence of project management competencies on project success.

Hypothesis $3\left(\mathbf{H}_{3}\right)$ : There is a positive influence of organisation strength on project success.

To test the above hypotheses, the methodology is given in the following section.

\section{RESEARCH METHODOLOGY}

Positivism is the research philosophy followed primarily for this research. Positivism is concerned with observing and predicting outcomes. It is a method used to propose and test theories with structured data in which research is independent of the researcher's values (Saunders \& Lewis, 2012). This type of research approach is deductive, in which hypotheses are made based on literature review, the data is analysed, and then the hypotheses are rejected or accepted according to the data analysis outcomes. A mixed-method approach comprising quantitative and qualitative research as a methodological choice has been chosen. The initial data has been collected through expert interviews. The results of these interviews have been used to develop a questionnaire. Then, the quantitative data collected through the questionnaires have been analysed using statistical techniques. The survey strategy has been used to collect data in a structured form by considering a suitable sample size. This collected data is cross-sectional. To obtain this type of data, the survey is undertaken to answer a question simultaneously, and multiple responses are collected (Saunders \& Lewis, 2012).

\section{Research Variables}

There are three latent variables named "Organisation Strength", "Project Management Competencies", and "Project Success". Organisation strength is used as the main independent variable. Organisation strength is further divided into three dimensions: Resources and Capabilities, Strategic Decisions, Relationship with other parties.

Project management competencies has been used as both the exogenous and the endogenous (in terms of SEM) variable as it is affecting project success and itself being affected by organization strength. Project success is kept as the main dependent variable in the proposed research model for this study.

\section{Measurement of Variables}

A preliminary list of measurement items and measurement scale of the study is adopted by the previous research on the performance measurement model by Isik et al. (2009). All the items are measured using a 7-point Likert scale ranging from "strongly agree" to "strongly disagree". Organisation strength is measured using three dimensions: resources and capabilities, strategic decisions, and strength of relationship with other parties. Resources and capabilities are measured using 11 indicators. Strategic decisions are measured using 10 indicators. The indicators of relationship with other parties referred to the company's relationship with its stakeholders. The project management competencies are measured with 10 indicators.

The dependent variable is project success, with 6 indicators connected to the successful accomplishment of projects within time, under budget, and full safety.

\section{Data Collection}

The secondary data has been collected through the systematic literature review. This review mainly focuses on gathering information and obtaining an understanding of organisation strength, project management competencies, project success, and their potential relationships.

After the detailed literature review, some questions were developed for interview purposes from project management experts in project management offices (PMOs). The project management office plays an important role in Construction organisations (Isik et al., 2009). The project management office (PMO) governs all the projects according to the organisation standards and policies. The project management offices in construction organisations improve the capabilities of organisations (Sergeeva \& Ali, 2020). Interviews were conducted with five (05) persons. The major purpose of those interviews was to obtain an expert opinion about key components of organisational strength, project management competencies, project success, and the potential effect of the first two upon the last one in the construction industry. Through these interviews, the importance of those factors in the construction projects of Rawalpindi and Islamabad was assessed.

A questionnaire was then designed incorporating the particularly mentioned indicators of organisation strength, project management competencies, and project success by above mentioned experts. Through a questionnaire, feedback of respondents was obtained about these variables. The respondents answered on a Likert scale ranging from 1-7, where 1 represented strongly disagree and 7 represented strongly agree. SPSS and SmartPLS softwares have been used for data analysis. 


\section{Sample Design}

The construction industry of Pakistan is chosen for the study. The data is collected from the construction companies of Islamabad and Rawalpindi. There are seventy (70) construction organisations, members of the Construction Association of Pakistan (CAP) in Rawalpindi and Islamabad. A convenient sampling technique is used for this study. Twenty (20) companies were selected based on their consent for participation in the study, and one hundred and fifty (150) questionnaires were circulated for data collection. The potential respondents returned one hundred and three (103) questionnaires. All the questionnaires were carefully checked for any mistakes and inappropriate responses. Six (06) questionnaires carried missing values; therefore, ninety-seven (97) responses have been used for final data analysis. The overall response rate has been $64.6 \%$ in this case.

\section{RESULTS AND ANALYSIS}

SmartPLS is used to analyse the data by employing the structural equation modelling (SEM) technique. Both measurement and structural models have been estimated to explain the proposed relationship among different variables for this research.

The reliability and validity of variables have been tested for the measurement model. Path analysis has been conducted to analyse the structural model and $\mathrm{R}$ square and adjusted $\mathrm{R}$ square values have also been estimated. The significance of the relationships among variables has been predicted through bootstrapping procedure.

The reliabilities are estimated using Cronbach's alpha and composite reliability. Cronbach's alpha is called the internal consistency reliability, which measures the extent to which items are closely related to each other as a group. The values of alpha, greater than 0.60 are considered acceptable for this purpose (Nunnally, 1994). For assessment of convergent validity, the average variance extracted (AVE) is measured. It measures the relationship among multiple items of a variable (Campbell \& Fisk, 1959), and its value should be $\geq 0.4$ (Hair et al., 2013). The values for Cronbach's alpha, composite reliabilities and AVE values are shown in table 1.

Table 1: Reliability and validity of measurement model

\begin{tabular}{llll}
\hline Latent Variables & Cronbach's alpha & Composite Reliability & AVE \\
\hline Organisation Strength & 0.935 & 0.943 & 0.59 \\
\hline Project Management Competencies & 0.846 & 0.881 & 0.56 \\
\hline Project Success & 0.748 & 0.775 & 0.49 \\
\hline
\end{tabular}

For measurement of the structural model, regression analysis is performed to predict the path coefficients of the proposed relationships among different variables. The significance of different relationships has also been measured to test the reliability of the standard estimates (beta coefficients). Bootstrapping is performed with sample size $=5000$ and cases $=97$.

Table 2: Regression and bootstrapping results of structural model

\begin{tabular}{llll}
\hline Relationships of variables & Beta Value & T.Value & Significance \\
\hline Organisation Strength $\rightarrow$ Project Management Competencies (H1) & 0.847 & $18.452^{* *}$ & 0.00 \\
\hline Project Management Competencies $\rightarrow$ Project Success (H2) & 0.530 & $6.226^{* *}$ & 0.00 \\
\hline Organisation Strength $\rightarrow$ Project Success (H3) & 0.400 & $4.694^{* *}$ & 0.00 \\
\hline
\end{tabular}

** Significant at 0.00

The t-values for beta coefficients are found significant at the level of 0.00 . $t$-values greater than 1.96 are considered significant. Standard estimates are the beta values which are the probability of rejecting or accepting the hypothesis (Hair et al., 2014). Standard estimates along with corresponding t-values of significance are shown in table 2.

The values of $\mathrm{R}$ square and adjusted $\mathrm{R}$ square have been calculated for estimation of model fitness. These values are presented in table 3. Organisation strength as an independent variable can cause a $71.7 \%$ variance in project Management Competencies. When combined with project management competencies, both can bring an $80 \%$ variance in Project success.

Table 3: $R$ square and adjusted $R$ square values

\begin{tabular}{lll}
\hline Relationships of variables & R Square & $\begin{array}{l}\text { Adjusted } \\
\text { R.Square }\end{array}$ \\
\hline Organisation Strength $\rightarrow$ Project Management Competencies & 0.717 & 0.714 \\
\hline Organisation Strength + Project management competencies $\rightarrow$ Project Success & 0.800 & 0.796 \\
\hline
\end{tabular}

The results of this study support the proposed relationship among the variables. It is traced that organisation strength influences project management competencies having a beta value of 0.847 and $t$-value 18.452 . This finding provides enough support for the confirmation of hypothesis H1 at both the construct and factor level. 
This research also reports the direct influence of "project management competencies" on project success. SmartPLS regression results show the significant positive impact of project management competencies on project success with a beta value of 0.530 and a t-value of 6.226. This result qualifies for the acceptance of hypotheses H2. Furthermore, organisation strength has a strong positive impact on project success with a beta value of 0.40 and a t-value of 4.694. Hence, hypothesis $\mathrm{H} 3$ is also accepted based on these results.

The indicators of the organisation strength are measured, and their importance is being analysed through the rating of the respondent companies. According to the rating of the respondents, the importance of the parameters is demonstrated. All the performance indicators of organisation strength are found to be important. This finding suggests that there is a need for organisation strength in the construction industry to measure performance. All three sub-components of organisation strength are also found to have high weights (see table 4).

Table 4: Factor weights

\begin{tabular}{llll}
\hline Relationships of organisation strength with its components & Factor weight & T-value & Significance \\
\hline Company resources and capabilities & 0.981 & 25.383 & 0.00 \\
\hline Strategic decisions & 0.95 & 11.698 & 0.00 \\
\hline Strength of relationship with other parties & 0.90 & 11.660 & 0.00 \\
\hline
\end{tabular}

The results suggest that company resources and capabilities determine organisation strength (Zuo et al., 2018) with a factor loading of 0.981 . Two indicators, "experience" and "technical competency", are found to be the most influential as compared to the other indicators. A competent technical team is very important for successful projects in construction companies. Experience also seems to be very important because lessons are learned through all previous projects. Financial resources are also found to be a clear indicator of organisation strength. Strategic decisions are the strong dimension of organisation strength, with a loading of 0.95. Project selection strategy is rated as the highest as compared to other strategies while "client selection" is rated as moderate. Networking Strength, with a factor loading of 0.90 , is a major indicator of "organisation strength". Among the strength of relationship with other parties, "Relations with client" is suggested to be an essential indicator. Relationship with a labour union is also found to be important. It seems important to have good relationships with labour union (Sergeeva \& Ali, 2020).

The results of this study are found to be consistent with theories in the existing literature. Organisation strength significantly influences project management competencies and project success (Rodríguez-Rivero et al., 2020).Project management competencies lead the project towards success (Madter et al., 2012; Chen et al., 2019; Rodríguez-Rivero et al., 2020). These researchers stressed the importance of project management competencies among other factors. Belout and Gauvreau (2004) have identified competencies associated with a project manager. In project-based industries like the construction industry, there is a direct link between projects management competencies and project success (Chen et al., 2019).

Among the project management competencies, the essential and most influential are cost management, human resource management and procurement management. The indicators measuring project success are: time, cost, quality, safety, performance, effectiveness, and stakeholder satisfaction. All the project success indicators are equally important except project safety to survive a project and develop future strategies. The low ranking of project safety suggests improving the safety standards to avoid potential harmful risks for the projects.

\section{DISCUSSION}

The current study finds that organization strength and project management competencies have strong ability to influence project success. It is also found that organisation strength has a significant relationship that positively influences competencies and project success. The beta coefficients are 0.847 and 0.4 with respective $t$-values of 18.452 and 4.694 for these two mentioned relationships (table 2). Project management competencies also affect the project success positively and significantly having values of beta coefficient 0.53 and t-value 6.226 (see table 2). Furthermore, organisation strength and project management competencies jointly affect the project success significantly. The value of $\mathrm{R}$ square for this relationship is 0.8 (see table 3); it means that these two former variables tend to cause $80 \%$ variance in the latter variable. Overall, the results of this study support the already proposed relationships.

Resources and capabilities are important contributors to organisation strength, having a factor weight of 0.981 and tvalue 25.383 (see table 4). Through literature, it has been traced that organisation resources and capabilities have valiant importance. Reviewing the literature, it has also been observed that the organisation's strength becomes the opportunity for the organisation (Zuo et al., 2018; Saad et al., 2020). To have a high positive impact of organisation strength on project success, organisations should prioritise its strength factors. The resources and capabilities can be used as a source of competitive advantage. Construction organisation's equipment, workforce, technical and managerial information, efficiency, cost-effectiveness are important to gain an advantage over the competitors (Chen et al., 2019). Leadership is also the key factor in managing projects (Zuo et al., 2018). Research and development capability are considered the weapon of competition that helps in scheduling techniques and financial estimation. Labour union should feel satisfied with their managing staff (Westerveld et al., 2003). Zuo et al. (2018) also highlighted the importance of soft skills, 
stating that good labour relationships provide experienced people with slippery conditions through negotiation and fixed wages. Companies put effort to stable their labour union and avoid non-serious contractors.

Strategic decisions also contribute to organisation strength. Strategies guide that how organisations should move in the forward direction (David et al., 2013). Strategic decisions with a higher factor loading of 0.95 and a t-value of 11.698 (see table 4) present its significant relationship with project strength. Strategic decisions are critical for organisation from financial perspective (Rodríguez-Rivero et al., 2020). The loadings of project management strategies and organisational management strategies are high and advantageous to strategic decisions.

Strength of relationship with other parties is another significant component of Organisation strength as it is evident having factor loading of 0.9 and a t-value of 11.66 (see table 4). It becomes clearer that these three, company recourses and capabilities, strategic decisions, and networking strength, are dimensions of organisation strength.

\section{CONCLUSION}

The current study finds that organization strength and project management competencies sturdily influence project success. It is also found that organisation strength has a significant relationship that positively influences project management competencies and project success. This research also proves the joint influence of organisation strength and project management competencies on project success. To gain project success, companies should focus on their strength and apply project management competencies intelligently based on the criteria of project success. The objectives of this research were accomplished by investigating this important phenomenon in project management and the business domain.

\section{LIMITATION OF THE RESEARCH}

Geographically, this study is conducted in one country that is Pakistan and specifically in its two cities; Rawalpindi and Islamabad. The data is collected only from the construction industry. Only PMO (project management office) individuals who worked in construction organisations of Rawalpindi and Islamabad were involved in the study.

\section{APPLICATION-OF THE STUDY}

The findings have offered an insight that how different types of organisations strengths impact project management competencies and also project success or organisation performance. The findings in this study also have the potential to act as a catalyst to further research in these areas in many ways. The investigation points out that the organisation's perception of the organisation's strength and overall project success might be dependent and related to each other. An organisation needs attention in organisational structure, organisational leadership, organisation culture and etc. There is a need for future research on organisation strength and its effect on project success. Future empirical research will be needed to assess the role of these entities as a variable of the performance measurement model, including the project management competencies, organisation strength and project success. Researchers have aligned the perception of management competencies, organisation strength and project success side by side. The present study provides empirical evidence and offers insight into the three connected variables. Particularly this study reveals that the organisations having a keen interest in enhancing their strengths and strive in this regard are the most successful and survive for a long time. The project success measurement model presented in this study may facilitate the organisations to make their place at the international level in the business world.

\section{ACKNOWLEDGEMENT}

We would like to thank all the independent reviewers of HSSR for their suggestions for improvement of this research work.

\section{AUTHORS CONTRIBUTION}

Samman Ayyaz and Rao Aamir Khan contributed towards writing, designing and organisation of the article. Sohail Aslam, Muhammad Khushnood, and Humera Manzoor performed the statistical analyses, interpretations and writeup finalization. All the author(s) have a significant contribution towards this research article.

\section{REFERENCES}

1. Abdul-Aziz, A. R., \& Kassim, P. J. (2011). Objectives, success, and failure factors of housing public-private partnerships in Malaysia. Habitat International, 35(1), 150-157. https://doi.org/10.1016/j.habitatint.2010.06.005

2. Abdul-Rahman, H., Wang, C., \& Muhammad, N. A. B. (2011). Project performance monitoring methods used in Malaysia and perspectives of introducing EVA as a standard approach. Journal of civil engineering and management, 17(3), 445-455. https://doi.org/10.3846/13923730.2011.598331

3. Alzahrani, J. I., \& Emsley, M. W. (2013). The impact of contractors' attributes on construction project success: A post-construction evaluation. International journal of project management, 31(2), 313-322. https://doi.org/10.1016/j.ijproman.2012.06.006

4. Arslan, G., \& Kivrak, S. (2008). Critical factors to company success in the construction industry. World Academy of Science, Engineering and Technology, 45(1), 43-46. 
5. Belout, A., \& Gauvreau, C. (2004). Factors influencing project success: the impact of human resource management. International journal of project management, 22(1), 1-11. https://doi.org/10.1016/S02637863(03)00003-6

6. Bocken, N. M., \& Geradts, T. H. (2020). Barriers and drivers to sustainable business model innovation: Organisation design and dynamic capabilities. Long Range Planning, 53(4), 1-52. https://doi.org/10. 1016/j.1rp.2019.101950

7. Campbell, D. T., \& Fiske, D. W. (1959). Convergent and discriminant validation by the multi-trait-multimethod matrix. Psychological Bulletin, 56(2), 81. https://doi.org/10.1037/h0046016

8. Castro, M. S., Bahli, B., Barcaui, A., \& Figueiredo, R. (2020). Does one project success measure fit all? An empirical investigation of Brazilian projects. International Journal of Managing Projects in Business, 14(3), 788-805. https://doi.org/10.1108/IJMPB-01-2020-0028

9. Chen, T., Fu, M., Liu, R., Xu, X., Zhou, S., \& Liu, B. (2019). How do project management competencies change within the project management career model in large Chinese construction companies? International Journal of Project Management, 37(3), 485-500. https://doi.org/10.1016/j.ijproman.2018.12.002

10. Choudhry, R. M., Hinze, J. W., Arshad, M., \& Gabriel, H. F. (2012). Subcontracting practices in the construction industry of Pakistan. Journal of Construction Engineering and Management, 138(12), 1353-1359. https://doi.org/10.1061/(ASCE)CO.1943-7862.0000562

11. Daniel, S., Agarwal, R., \& Stewart, K. J. (2013). The effects of diversity in global, distributed collectives: A study of open-source project success. Information Systems Research,24(2), 312-333. https://doi.org/10.12 $\underline{\text { 87/isre.1120.0435 }}$

12. David, F. R., David, F. R., \& David, M. E. (2013). Strategic management: Concepts and cases: A competitive advantage approach. Upper Saddle River: Pearson.

13. de Bakker, K., Boonstra, A., \& Wortmann, H. (2012). Risk managements' communicative effects influencing IT project success. International Journal of Project Management,30(4), 444-457. https://doi.org/10.101 6/j.ijproman.2011.09.003

14. Doloi, H. (2009). Analysis of pre-qualification criteria in contractor selection and their impacts on project success. Construction Management and Economics, 27(12), 1245-1263. https://doi.org/10.1080/01446 190903394541

15. Fells, M. J. (2000). Fayol stands the test of time. Journal of Management History, 6(8), 345-360. https://doi.org/10.1108/13552520010359379

16. Frödell, M., Josephson, P. E., \& Lindahl, G. (2008). Swedish construction clients' views on project success and measuring performance. Journal of Engineering, Design and Technology, 6(1), 21-32. https://doi.org/10.1108/17260530810863316

17. Ghoddousi, P., \& Hosseini, M. R. (2012). A survey of the factors affecting the productivity of construction projects in Iran. Technological and economic development of economy, 18(1), 99-116. https://doi.org/10.3846/20294913.2012.661203

18. Gudienè, N., Banaitis, A., Podvezko, V., \& Banaitienè, N. (2014). Identification and evaluation of the critical success factors for construction projects in Lithuania: AHP approach. Journal of Civil Engineering and Management, 20(3), 350-359. https://doi.org/10.3846/13923730.2014.914082

19. Gumilar, V., Zarnić, R., \& Selih, J. (2011). Increasing competitiveness of the construction sector by adopting innovative clustering. Engineering Economics, 22(1), 41-49. https://doi.org/10.5755/j01.ee.22.1.217

20. Hair Jr, J. F., Sarstedt, M., Hopkins, L., \& Kuppelwieser, V. G. (2014). Partial least squares structural equation modeling (PLS-SEM): An emerging tool in business research. European Business Review, 26(2), 106-121. https://doi.org/10.1108/EBR-10-2013-0128

21. Hair, J. F., Ringle, C. M., \& Sarstedt, M. (2013). Partial least squares structural equation modeling: Rigorous applications, better results, and higher acceptance. Long range planning,46(1-2), 1-12. https://doi.org/10.1016/j.lrp.2013.01.001

22. Hany Abd Elshakour, M. A., Al-Sulaihi, I. A., \& Al-Gahtani, K. S. (2013). Indicators for measuring performance of building construction companies in Kingdom of Saudi Arabia. Journal of King Saud UniversityEngineering Sciences, 25(2), 125-134. https://doi.org/10.1016/j.jksues.2012.03.002

23. Hwang, B. G., \& Ng, W. J. (2013). Project management knowledge and skills for green construction: Overcoming challenges. International journal of project management, 31(2), 272-284. https://doi.org/10.10 16/j.ijproman.2012.05.004

24. Isik, Z., Arditi, D., Dikmen, I., \& Birgonul, M. T. (2009). Impact of corporate strengths/weaknesses on project management competencies. International Journal of Project Management, 27(6), 629-637. https://doi.org/10.1016/j.ijproman.2008.10.002

25. Kulshreshtha, P. (2008). Public sector governance reform: The World Bank's framework. International Journal of Public Sector Management, 21(5), 556-567. https://doi.org/10.1108/09513550810885831

26. Lieshout, E. C. V., van de Port, I. G., Dijkhuizen, R. M., \& Visser-Meily, J. M. (2020). Does upper limb strength play a prominent role in health-related quality of life in stroke patients discharged from inpatient $\begin{array}{lll}\text { rehabilitation?. Topics in } & \text { Stroke } & \text { Rehabilitation, 27(7), } \\ \text { https://doi.org/10.1080/10749357.2020.1738662 } & & \end{array}$

525-533. 
27. Madter, N., Bower, D. A., \& Aritua, B. (2012). Projects and personalities: A framework for individualising project management career development in the construction industry. International Journal of Project Management, 30(3), 273-281. https://doi.org/10.1016/j.ijproman.2011.09.001

28. Meng, X. (2012). The effect of relationship management on project performance in construction. International journal of project management, 30(2), 188-198. https://doi.org/10.1016/j.ijproman.2011.04.002

29. Mir, F. A., \& Pinnington, A. H. (2014). Exploring the value of project management: linking project management performance and project success. International journal of project management, 32(2), 202-217. https://doi.org/10.1016/j.ijproman.2013.05.012

30. Müller, R., Geraldi, J., \& Turner, J. R. (2011). Relationships between leadership and success in different types of project complexities. IEEE Transactions on Engineering Management, 59(1), 77-90. https://doi.org/10.1109/ TEM.2011.2114350

31. Müller, R., Glückler, J., \& Aubry, M. (2013). A relational typology of project management offices. Project Management Journal, 44(1), 59-76. https://doi.org/10.1002/pmj.21321

32. Munns, A. K., \& Bjeirmi, B. F. (1996). The role of project management in achieving project success. International journal of project management, 14(2), 81-87. https://doi.org/10.1016/02637863(95)00057-7

33. Ng, S. T., Tang, Z., \& Palaneeswaran, E. (2009). Factors contributing to the success of equipment-intensive subcontractors in construction. International Journal of Project Management,27(7), 736-744. https://doi.org/10.1016/j.ijproman.2008.09.006

34. Nunnally, J. C. (1994). Psychometric theory 3E. Tata McGraw-hill education.

35. Pheng, L. S., \& Chuan, Q. T. (2006). Environmental factors and work performance of project managers in the construction industry. International journal of project management, 24(1), 24-37. https://doi.org/10.1016 /j.ijproman.2005.06.001

36. Project Management Institute. (2017). A guide to the Project Management Body of Knowledge (PMBOK guide) (6th ed.). Project Management Institute.

37. Remidez, H., \& Jones, N. B. (2012). Developing a model for social media in project management communications. International Journal of Business and Social Science, 3(3).

38. Rodríguez-Rivero, R., Ortiz-Marcos, I., Díaz-Barcos, V., \& Lozano, S. A. (2020). Applying the strategic prospective approach to project management in a development project in Colombia. International Journal of Project Management, 38(8), 534-547. https://doi.org/10.1016/j.ijproman.2020.07.003

39. Saad, A., Zahid, S. M., \& Muhammad, U. B. (2020). Role of awareness in strengthening the relationship between stakeholder management and project success in the construction industry of Pakistan. International Journal of Construction Management, 1-10. https://doi.org/10.1080/15623599.2020.1742854

40. Saqib, M., Farooqui, R. U., \& Lodi, S. H. (2008, August). Assessment of critical success factors for construction projects in Pakistan. In First International Conference on Construction in Developing Countries (pp. 392-404).

41. Saunders, M. N., \& Lewis, P. (2012). Doing research in business \& management: An essential guide to planning your project. Pearson.

42. Sergeeva, N., \& Ali, S. (2020). The role of the Project Management Office (PMO) in stimulating innovation in Projects initiated by Owner and Operator Organisations. Project Management Journal, 51(4), 440-451. https://doi.org/10.1177/8756972820919215

43. Shahhosseini, V., \& Sebt, M. H. (2011). Competency-based selection and assignment of human resources to construction projects. Scientia Iranica, 18(2), 163-180. https://doi.org/10.1016/j.scient.2011.03.026

44. Shin, Y. (2012). CEO ethical leadership, ethical climate, climate strength, and collective organisational citizenship behavior. Journal of Business Ethics, 108(3), 299-312. https://doi.org/10.1007/s10551-011-1091-7

45. Tan, H. C., Carrillo, P. M., Anumba, C. J., Bouchlaghem, N., Kamara, J. M., \& Udeaja, C. E. (2007). Development of a methodology for live capture and reuse of project knowledge in construction. Journal of management in engineering, 23(1), 18-26. https://doi.org/10.1061/(ASCE)0742-597X(2007)23:1(18)

46. Turner, J. R., \& Downey, A. B. (1993). The handbook of project based. Management, McGraw-Hill, Boston.

47. Upadhyay, P., \& Kumar, A. (2020). The intermediating role of organisational culture and internal analytical knowledge between the capability of big data analytics and a firm's performance. International Journal of Information Management, 52, 1-16. https://doi.org/10.1016/i.ijinfomgt.2020.102100

48. Westerveld, E. (2003). The Project Excellence Model®: linking success criteria and critical success factors. International Journal of project management,21(6), 411-418. https://doi.org/10.1016/S0263$\underline{7863(02) 00112-6}$

49. Zuo, J., Zhao, X., Nguyen, Q. B. M., Ma, T., \& Gao, S. (2018). Soft skills of construction project management professionals and project success factors. Engineering, Construction and Architectural Management, 25(3), 425-442. https://doi.org/10.1108/ECAM-01-2016-0016 